\title{
Fertility Intentions in Canada: Change or No Change?
}

\section{Barry Edmonston}

Department of Sociology

and Population Research Group

University of Victoria

Victoria, British Columbia

E-mail: be@uvic.ca

\section{Sharon M. Lee}

Department of Sociology

and Population Research Group

University of Victoria

Victoria, British Columbia

\section{Zheng Wu}

Department of Sociology and Population Research Group

University of Victoria

Victoria, British Columbia

\begin{abstract}
This paper describes trends in fertility intentions in Canada based on an analysis of data from four national household surveys -- General Social Surveys in 1990, 1995, 2001, and 2006. The study finds that the fertility intentions of Canadian women have been relatively stable for the past 16 years, moving within a narrow range of 2.11 to 2.29 children. Modest decreases due to changes in population composition - and not changes in the relationship between various explanatory variables and intended fertility - have largely been responsible for the modest overall decrease of 0.08 children in intended fertility between 1990 and 2006.
\end{abstract}

Key Words: Fertility intentions, fertility trends, low fertility 


\begin{abstract}
Résumé
Cet article décrit les tendances en matière des intentions de fécondité au Canada en se basant sur une analyse des données de quatre enquêtes auprès des ménages - les Enquêtes sociales générales de 1990, 1995, 2001 et 2006. Les résultats de cette étude démontrent que les intentions de fertilité des Canadiennes sont restées relativement stable pendant les derniers 16 ans, et se situent dans la marge étroite de 2.11 à 2.29 enfants. De faibles baisses causées par des changements dans la composition de la population - et non par des changements dans la relation entre divers explicatifs variables et la fécondité désirée - ont été largement responsable pour le faible déclin général de 0.08 enfant dans le taux de fécondité désirée entre 1990 et 2006.
\end{abstract}

Mots clés : Intentions de fécondité, tendances en matière de fécondité, chute de la fécondité

\title{
Introduction
}

This paper describes a study of factors associated with fertility intentions in Canada using data from the 1990, 1995, 2001, and 2006 General Social Surveys conducted by Statistics Canada. We have two objectives. First, we describe trends in fertility intentions for the 1990 to 2006 period and the relationship of various factors such as age and education with fertility intentions. Second, we examine the role of changes in population composition and changes in the effects of selected factors, such as education, employment and family structure, on trends in fertility intentions during the 1990 to 2006 period. Although there have been several studies of factors related to fertility in Canada (see Baker 1994, Beaujot 1994, Bélanger and Gilbert 2006, Ram 1994 and Romaniuc 1995), relatively few studies have focussed on fertility intentions (see Dupuis 1998, and Beaujot and Muhassmud 2005 for exceptions).

In an "ideal" world, a woman would bear the number of children that she reports she would like to have. In this ideal situation, a woman's stated fertility preferences would be a fairly close indicator of her completed fertility. This is not the case for many countries (Hagewan and Morgan 2005). The Fertility and Family Survey project, which interviewed women in 18 European countries as well as Canada and New Zealand, ${ }^{1}$ found that women said that they wanted about 2.1 children - 
ranging from 2.0 children in Austria to 2.3 children in France, Poland, and the United States (Bongaarts 2002: Table 2). However, actual completed fertility for these women averaged about 1.8 children, or 0.3 children fewer than the number wanted (Bongaarts 2002: Table 2). In some countries, such as Hungary, the difference of 0.1 child was minor. In other cases, such as Italy, Spain, and Sweden, the difference was almost 0.5 children, a major difference between desired and actual completed fertility.

We investigate trends in, and factors associated with, fertility intentions in Canada. In a later section, reasons for differences between intended and observed fertility are discussed.

\section{Studying Fertility Intentions}

Measures of fertility intentions and fertility behaviour are often different. The dominant pattern in most developed countries is for fertility intentions to substantially exceed levels of observed fertility. Recent data show fertility intentions close to or above 2.0 for several European Union countries and the United States, while total fertility rates are below replacement level, except for the United States where both are at or slightly above 2.0 (Hagewen and Morgan 2005: Figure 1). As discussed later in this paper, fertility intentions in Canada have been around 2.20 in the $1990 \mathrm{~s}$ while the total fertility rate was lower, around 1.5 to 1.7.

The gap between intended and observed fertility has led to different perspectives among demographers on the relationship between fertility intentions and observed fertility, and the value of studying fertility intentions. Hagewen and Morgan (2005) summarize the three main perspectives (though not necessarily mutually exclusive), as follows: (1) fertility will soon rise to more closely resemble fertility intentions, as suggested by Bongaarts (2002); (2) fertility intentions will soon fall to more closely resemble observed fertility, as suggested by Goldstein et al. (2003); and (3) the gap between fertility intentions and fertility will persist, as suggested by Demeny (2003).

These three perspectives suggest different approaches to the relevance and utility of fertility intentions in fertility research. For example, Demeny's (2003) perspective suggests that data on preferences and intentions may be irrelevant. Hagewen and Morgan (2005), however, provide two important reasons in support of the relevance and importance of data and research on fertility intentions. First, there is an extensive theoretical and empirical literature on the predictive validity of reproductive intentions. According to Schoen et al. (1997: 340), "the same factors that predicted fertility behaviour predicted fertility 
intentions" and "intentions play the primary mediating role between background and adult role variables on the one hand and measures of the transition to parenthood on the other". Several studies also report fairly close correspondence between fertility intentions and behaviour (Quesnel-Vallée and Morgan 2003; Schoen et al. 1999). Second, in low fertility populations concerned with population decline and aging, the disjuncture between individuals' expressed fertility intentions and realized fertility, and society's interest in raising fertility rates, represent a significant opportunity for policy interventions that, on the one hand, help individuals realize their fertility intentions and, on the other hand, contribute to population growth.

We agree with Hagewen and Morgan (2005: 510) that "fertility intentions take on a central (emphasis in the original) role in understanding fertility trends" and that "intentions or expectations operate as a key mediating or proximate variable in predicting fertility behavior". Our more general theoretical framework is based on previous work by Bongaarts $(2001,2002)$ and Morgan (2003) who model fertility variations with reference to differences across groups in fertility intentions, fertility timing, contraceptive failure, infecundity, and competition with work and other time intensive or desirable activities. Other researchers, for example Hakim (2003), have discussed the importance of subjective and psychological factors such as individual preferences in understanding fertility, but these factors are not as easily measured or modeled.

Three dimensions are implicated in responses to questions about fertility intentions. First, there is a normative dimension, in which respondents frame their ideas about fertility based on social norms. Demographers have asked questions such as "what do you think is the ideal family size" in some surveys for example, in order to understand social norms about fertility. These social norms might be conditioned by a person's religious affiliation, number of siblings, and other factors that affect thinking about how many children one should ideally have. Second, there is a behavioural dimension, in which respondents think about their fertility intentions based on their current and near future situation. Someone who has recently married, bought a home, and is planning to start a family would likely answer a survey question about fertility intentions based on her current individual situation. Third and finally, there is an achieved dimension, in which respondents answer a question on fertility intentions based on completed or achieved childbearing. This would be likely among older women when it is apparent that childbearing is almost completed.

These three dimensions vary over a woman's lifecycle, although probably all three are intertwined in a woman's reporting of fertility 
intentions. For younger women who are not in a marital or common-law union and may still be living with their parents, a question on fertility intentions may elicit a response based primarily on social norms because they have no immediate plans for childbearing and longer-term childbearing plans are fairly abstract and hypothetical. For a young woman in a marital or common-law union who has recently had a first child, a question on fertility intentions is highly relevant and would be considered based on her current situation; in this case, the behavioural dimension is dominant. Finally, for an older woman who believes that she has completed her childbearing, a question about fertility intentions would elicit a reply indicating that her overall fertility intentions are the same as her completed childbearing.

There are two important implications of this life cycle perspective on analyzing and interpreting fertility intentions. First, it is important to analyze data on fertility intentions from the point-of-view of a woman's life cycle stage (usually approximated by her age and marital status). An analysis of data on fertility intentions from the 1995 General Social Survey highlights the importance of age and marital status: average number of children intended was highest among respondents in their $20 \mathrm{~s}$ and decreased among respondents in their $30 \mathrm{~s}$ and $40 \mathrm{~s}$, and married respondents reported higher fertility intentions (Dupuis 1998). Second, the interpretation of the relationship of a woman's age and marital status, as well as her fertility intentions needs to be based on the changing meaning of "fertility intention" over the life cycle: it relates much more to "idealized" desires for younger women and relates for the most part to achieved fertility for older women. In addition, fertility intentions can change as people age and their life circumstances change. Dupuis (1998) reported that a comparison of fertility intention data among several cohorts of women collected from the 1984 Canadian Fertility Survey and the 1995 General Social Survey showed declines in fertility intentions, underlining the need to interpret fertility intention data with appropriate caution, as we discuss below.

\section{Using and Interpreting Data on Fertility Intentions}

There are two main uses of data on fertility intentions or expectations. One prominent use in demography has been to estimate completed fertility levels for cohorts of women still in their childbearing years. This has been an important use for population projections because such projections need to make assumptions about the future course of fertility. Most demographers are willing to consider fertility intention data as reasonable indicators of changes in the eventual levels of fertility. 
Research cited by Bongaarts (2002) does not support the use of fertility intentions data for making precise estimates of future fertility (see for example, Freedman et al. 1965). Changes in fertility intentions, however, are useful for suggesting that future fertility may increase or decrease, depending upon the direction of shifts in intentions.

A second major use of fertility expectation or intention data is to inform our understanding of the dynamics of fertility change. In this case, we analyze fertility intention data to note changes over time and the association between fertility intention and important social, economic, and demographic factors. This paper focuses on this second use of fertility intention data.

\section{Data, Methods of Analysis, and Limitations}

This section describes the data sources, variables for analysis, and methods of analysis. We also address limitations of the study related to data and methods.

\section{Data Sources}

The main data source for this paper is the General Social Survey (GSS), Canada's largest national annual general purpose social survey. The GSS program began in 1985 and conducts a large telephone survey each year. The survey sample size was about 10,000 respondents from 1985 to 1998. In 1999 and continuing to the present, the sample size was expanded to about 25,000 respondents in order to provide provincial estimates and national estimates for smaller population groups, such as visible minorities. The current survey interviews respondents 15 years of age or older, who are randomly selected within households. The survey includes questions about the respondent's age, sex, marital status, educational attainment, nativity, occupation and work experience, and other social and economic characteristics.

The GSS includes special modules each year that collect more detailed information on topics of interest. The 1990 (Cycle 5), 1995 (Cycle 10), 2001 (Cycle 15), and 2006 (Cycle 20) General Social Surveys include a module on family transition, including questions on family origin, marriages and common-law unions of respondent, fertility and family intentions, births and adoption, social networks, work-family balance, and maternity/paternity leave history. 
For the study of trends over time, we analyze the 1990, 1995, 2001, and 2006 public-use data (see Statistics Canada, 1992, 1997, 2003, and 2008a for information on data documentation), which provide an appropriate data set for descriptive trend analysis and decomposition of trends using separate cross-sectional data. We include as many variables of interest for the study as are available and that have similar variable definitions and codes for all four surveys. The analysis uses the person sample weights provided by Statistics Canada for each cross-sectional data set.

The dependent variable for this study is fertility intentions. Fertility intentions are measured by two variables: the number of births that the respondent has had at the time of the survey and future intended births. These two variables together measure the total intended births for respondents. The study of fertility intentions or expectations has been carried out by demographers since at least the early 1950s. Ronald Freedman, for example, included a question about "how many children do you expect to have" in the Detroit Area Study in the early 1950s and then included the question in the pioneering Growth of the American Family survey in 1955 - the first national survey in the United States that asked women about their fertility behaviour and attitudes. Longitudinal survey data collected in the 1960s suggested that aggregate fertility intentions provided a useful guide about subsequent fertility behaviour (Freedman et al.. 1965). Nevertheless, fertility intentions are not "perfect predictors" of behaviour. Longitudinal data reveal that some women have more children than intended and some have fewer. Good aggregate prediction does not imply perfect individual prediction.

Survey questions about fertility intentions are limited to respondents aged 15 to 44 years in the 1990 General Social Survey and aged 15 to 49 in the other three General Social Surveys. We therefore restrict analysis to respondents who are aged 15 to 44 years. We further limit attention to women ${ }^{2}$ who are in married or common-law unions to sharpen the focus on women whose social situation is more immediately pertinent to a study of fertility intentions and because data in the General Social Survey on fertility intentions are mainly limited to adults in married or common-law unions. In the 2006 GSS (Statistics Canada, 2008a: 343), question FI_Q110 "Do you intend to have a/another child sometime?" was asked of respondents who are "less than 50 years old and are married or live in common-law or respondent's partner is less than 50 years old and are married or live in common-law." If the respondent replied "yes" to FI_Q110, then they were asked a question about the total number of children that they intend to have. In the 2001 GSS (Statistics Canada, 2003: 117), respondents were asked if they intend to have more children only if they or their partner were less than 
50 years old and are not pregnant and are married or living common-law. The codebooks for the 1990 and 1995 present a complicated description for the selection of respondents on the fertility intention question, citing previous survey questions that are not available in the public-use data files. Nevertheless, because data on fertility intentions are limited to respondents who are in married or common-law unions in the 2001 and 2006 General Social Surveys, we limit analysis to this category of respondents.

The selection of explanatory variables is guided by the literature review of factors related to fertility intentions (see Edmonston, Lee and Wu 2008) and the availability of variables common to the 1990, 1995, 2001, and 2006 General Social Surveys. The main variables included in this study are age, the survey period, employment status, occupation, household income, educational attainment, work-family balance, social ties and support, family structure (type of union and number of persons in the household), infertility and health, geography, nativity (including foreign-birth, recency of immigration, and age at immigration), and social origins (including ethnic origin, religion, and home language).

\section{Methods of Analysis}

One objective of this research is to examine how trends in fertility intentions have been due to changes in the composition of the Canadian population. We provide statistical analysis for this objective using a demographic technique for the decomposition of rates. We estimate a regression equation for each survey year - 1990, 1995, 2001, and $2006-$ that includes the same explanatory variables in the prediction of fertility intentions. This analysis relies on separate cross-sectional surveys. The explanatory variables include ones available in each of the survey years and are described in a following section describing the decomposition analysis.

The decomposition of change in rates (in this case, the "rates" are fertility intentions) involves two calculations for each period of time. If 1990 is the first period of time and 1995 is the second period of time, the first calculation involves the change in the composition of the population between 1990 and 1995. This is achieved by calculating the change in the category weights for each explanatory variable between the two periods. The change in category weights is multiplied by the regression coefficients in the 1995 regression equation to reveal the amount of change in overall fertility intentions due to change in the composition of the population. 
The second calculation involves calculating the change in regression coefficients between 1990 and 1995. In this case, this is achieved by multiplying the change in regression coefficients by the 1995 category weights. This reveals the difference in fertility intentions that is due to changes in the relationship of the variables with fertility intentions.

If we subtract the overall level of fertility intentions in 1990 from the overall level in 1995, it is comprised of three factors: (a) the difference due to changes in population composition, (b) the difference due to changes in the estimated regression coefficients, and (c) the difference due to the interaction of (a) and (b) factors. In practice, the difference due to the interaction is generally small. In this research, this analysis helps us to understand the sources of change for possible differences over time in fertility intentions. We calculate a decomposition of rates for changes from 1990-1995, 1995-2001, 20012006, and the overall change from 1990-2006.

\section{Decomposition of Differences Model}

The decomposition of differences of rates follows an approach originally proposed by Evelyn Kitagawa (1955) and subsequently elaborated by others (see DasโGupta, 1994 for a more recent discussion). Consider two crude rates, $\mathrm{R}^{1}$ and $\mathrm{R}^{2}$, which are the sum of the products of the proportion of observations at age $a$ and the rate at age $a$. We can write:

$$
R^{1}=\sum c_{a}^{1} f_{a}^{1}
$$

and

$$
R^{2}=\sum c_{a}^{2} f_{a}^{2}
$$

For example, if $\mathrm{R}^{1}$ and $\mathrm{R}^{2}$ were crude death rates for men and women, respectively, then they can be written as the sum of the products of the proportion of men or women at age $a$ times the age-specific death rate at age $a . \mathrm{R}^{1}$ minus $\mathrm{R}^{2}$ is the difference between the two rates and can be written as:

$$
R^{1}-R^{2}=\sum c_{a}^{1} f_{a}^{1}-\sum c_{a}^{2} f_{a}^{2}
$$


Now, define the change in composition and the change in rates for age a as:

$$
\Delta c=c_{a}^{1}-c_{a}^{2} \quad \text { and } \quad \Delta f=f_{a}^{1}-f_{a}^{2}
$$

or

$$
c_{a}^{1}=c_{a}^{2}+\Delta c \quad \text { and } \quad f_{a}^{1}=f_{a}^{2}+\Delta f
$$

We can rewrite the difference between the two rates as:

$$
R^{1}-R^{2}=\sum c_{a}^{1} f_{a}^{1}-\sum c_{a}^{2} f_{a}^{2}=\sum\left(c_{a}^{2}+\Delta c\right)\left(f_{a}^{2}+\Delta f\right)-\sum c_{a}^{2} f_{a}^{2}
$$

After rearranging the terms and simplifying, we have:

$$
R^{1}-R^{2}=\sum \Delta c f_{a}^{2}+\sum c_{a}^{2} \Delta f+\sum \Delta c \Delta f
$$

which decomposes the difference between two rates into three factors: (a) the first is the difference in rates due to change in the composition, (b) the second is the difference due to change in the rates, and (c) the third is the difference due to the combination of change in the composition and the change in rates. The third factor is usually small because it indicates correlated changes that occur in the same direction - both are positive or both are negative - and is sometimes referred to as the interaction term.

Although the exposition above refers to age as the category for rates and composition, this is presented here as an example. The rates could be based on other specific categories, such as education by highest degree or ethnic origin by types of ethnicity.

This general approach is used for the decomposition of differences in intended fertility between the four periods of the General Social Survey. Because the decomposition of differences in this analysis is based on four regression equations, the discussion of rates is in terms of regression coefficients and the discussion of composition is in terms of category weights. 
The following six steps are used for the decomposition of differences for regression equations:

1. Estimate regression equations separately for 1990, 1995, 2001, and 2006.

2. For categorical variables, calculate the category weights as the proportion of observations in each category of the variable. For province, for example, we calculate the proportion of all observations reporting their residence in each of the ten provinces.

3. For continuous variables, the weights are calculated as the mean of observations for the particular continuous variable.

4. The difference in rates due to change in composition is calculated by multiplying the difference in category weights between time 1 and time 2 by the regression coefficients at time 2 . This indicates how much change in intended fertility would have occurred due to changes in the composition of the population. In order to allocate how much of the difference is due to each variable, the difference in the category weights for one variable is changed, one at a time, and noting the effect.

5. The difference in regression coefficients (or, "rates" in the original example above) is calculated by multiplying the difference in regression coefficients between time 1 and time 2 by the category weights at time 1 . This indicates how much change in intended fertility would have occurred due to changes in regression coefficients between the two periods. The difference due to each variable is calculated by taking the difference in regression coefficients for each variable, one at a time, and noting the effect.

6. The difference due to the interaction term is calculated by multiplying the difference in category weights between time 1 and time 2 by the difference in regression coefficients between time 1 and time 2. The method described in the previous steps allocates the difference due to each variable to either change in composition or change in rates and we do not calculate an interaction term for each variable. As a result, the sum of the differences due to composition for each variable may not equal exactly to the overall difference due to composition. The same caution applies to the sum of the differences due to rates for each variable. 


\section{Limitations}

Although the four GSS datasets provide an opportunity to examine variations and changes over time in fertility intentions, there are potential limitations that affect the empirical findings. The cross-sectional design of the GSS complicates investigating age or aging effects. With crosssectional data, it is impossible to distinguish changes over time within individuals, or aging effects, from differences between individuals, or cohort effects (Diggle et al. 1994).

Another limitation of the data also arises from its cross-sectional design, which is unsuitable for determining causal relationships. A primary objective of this research is to study the effects of selected variables on fertility intentions, which implies a causal relationship. Clearly, one cannot extract unambiguous causal knowledge or demonstrate causality from non-experimental observational data (Moffitt 2005), although there have been attempts to overcome these obstacles (see for example, Rubin 1974). The objective of this research is therefore more limited. We examine the relationship between selected variables and intended fertility and investigate how this relationship may change with age and over time. Models are specified that account for the effects of confounding factors and rule out explanations that are inconsistent with the empirical evidence.

In addition to data concerns, there were social and policy changes in Canada during the 1990 to 2006 period that might affect fertility intentions. Changes such as different eligibility for paternal leave and childcare could conceivably affect fertility intentions. Such social changes, however, are not examined in this research. In general, we take a cautious approach when interpreting our findings.

\section{Results}

Overall, mean intended fertility fluctuated over the 1990 to 2006 period within a fairly narrow range (see Table 1). Mean intended fertility for Canadian women in married or cohabiting unions rose from 2.19 in 1990 to 2.21 in 1995, and 2.29 in 2001 before declining to 2.11 in 2006. For the four General Social Survey files combined, mean intended fertility was 2.20 for the overall 1990-2006 period.

About one-half of Canadian women report that they intend to have 2 children. The second most common intention (for 23 percent of women) is to have 3 children. About 8 percent intend to have 4 children 
Table 1

Number of Intended Children and Descriptive Statistics for Intended Fertility, Women in Married or Common-Law Unions, 15 to 44 Years of Age, for Canada: 1990, 1995, 2001 and 2006

\begin{tabular}{|c|c|c|c|c|c|}
\hline & 1990 & 1995 & $\begin{array}{l}\text { Year } \\
2001\end{array}$ & 2006 & Total \\
\hline & \multicolumn{5}{|c|}{ Percentage Distribution by Number of Intended Children } \\
\hline \multicolumn{6}{|l|}{ Number } \\
\hline $\mathbf{0}$ & 7.7 & 7.2 & 7.0 & 7.7 & 7.4 \\
\hline 1 & 9.5 & 10.1 & 12.5 & 12.4 & 11.1 \\
\hline 2 & 50.0 & 48.9 & 43.8 & 50.7 & 48.3 \\
\hline 3 & 23.5 & 23.7 & 23.3 & 21.0 & 22.9 \\
\hline 4 & 7.5 & 8.4 & 7.7 & 6.3 & 7.5 \\
\hline 5 or more & 1.7 & 1.8 & 5.6 & 1.8 & 2.8 \\
\hline \multirow[t]{2}{*}{ All Women } & 100.0 & 100.0 & 100.0 & 100.0 & 100.0 \\
\hline & \multicolumn{5}{|c|}{ Descriptive Statistics } \\
\hline $\begin{array}{c}\text { Mean } \\
\text { Standard }\end{array}$ & 2.19 & 2.21 & 2.29 & 2.11 & 2.20 \\
\hline Deviation & 1.03 & 1.04 & 1.17 & 1.02 & 1.07 \\
\hline $\begin{array}{l}\text { Number of } \\
\text { Women }\end{array}$ & $3,386,186$ & $3,670,916$ & $3,506,503$ & $3,263,084$ & $13,826,768$ \\
\hline Sample Size & 2,378 & 1,854 & 3,651 & 3,118 & 11,001 \\
\hline
\end{tabular}

and 3 percent intend to have 5 or more children. ${ }^{3}$ About 11 percent intend to have 1 child. Childless intentions appear to be stable, with about 7 percent of women intending to have no children. The standard deviation for fertility intentions has been slightly over 1 for the four surveys, reflecting that the distribution of fertility intentions has not changed greatly and has centered on 2 children.

Mean intended fertility is expected to decrease with age. Based on prior research by John Bongaarts (2001 and 2002) and others, young people start their reproductive career with an idealized notion about the number of children that they would like to have. Over time, they experience the effects of two processes. First, if a woman does not begin childbearing until about age 30 or after, she is less likely to be able to have children even if she would like to have children. ${ }^{4}$ This occurs because advancing age is associated with anovulatory conditions for women or with medical operations that render either a woman or her 
partner unable to have children. We call the first process involuntary reasons for not having children.

The second process relates to voluntary reasons for not having children and is more complicated. While some women and men may increase their intentions for additional children as they age, most women and men find that other changes compete with childbearing and childraising, such as the higher opportunity costs of children for a woman with a well-paid career. With advancing age, many women and their partners decide to forego childbearing or to reduce the number of intended children. Together, both involuntary and voluntary processes associated with aging lead to decreases in mean intended fertility.

Table 2 shows the relationship of mean intended fertility with women's age for each of the four General Social Survey years. Mean intended fertility is generally highest for women aged 20 to 24 years. Women aged 20 to 24, who are married or in common-law unions, state that they intend to have about 2.3 to 2.7 children. As women age, their mean intended fertility declines to levels that are about 10 to 25 percent lower by age 35 and over.

\section{Regression Results}

We begin the multivariate analysis with an examination of the relationship of a common set of explanatory variables and intended fertility. The regression analysis includes the following sample sizes: 2,104 in 1990, 1,681 in 1995, 3,165 in 2001, and 2,769 in 2006.

Regression coefficients, standard errors, and t-values are estimated for each General Social Survey. Appendix Tables A1, A2, A3 and A4 present results for the 1990, 1995, 2001, and 2006 General Social Surveys, respectively. In addition to the standard regression estimates, we have calculated the predicted mean intended fertility for variable categories, holding all other variables at their observed mean. The predicted mean intended fertility is useful for examining the relationship of both nominal variables, which are coded as dummy variables in the regression analysis, and continuous variables. ${ }^{5}$

Rather than discuss each regression equation separately, we describe the consistency of relationship of each variable with intended fertility for the four equations as a group. 
Table 2

Mean Intended Fertility by Age Groups, Women in Married or Common-Law Unions, 15 to 44 Years of Age, for Canada: 1990, 1995, 2001 and 2006

\begin{tabular}{|c|c|c|c|c|c|}
\hline Age & 1990 & 1995 & $\begin{array}{l}\text { Year } \\
2001\end{array}$ & 2006 & Total \\
\hline Less than 20 & 2.44 & 2.06 & 2.45 & 2.27 & 2.31 \\
\hline $20-24$ & 2.28 & 2.43 & 2.73 & 2.36 & 2.44 \\
\hline $25-29$ & 2.30 & 2.31 & 2.57 & 2.31 & 2.36 \\
\hline $30-34$ & 2.18 & 2.14 & 2.46 & 2.25 & 2.25 \\
\hline $35-39$ & 2.06 & 2.20 & 2.18 & 2.05 & 2.13 \\
\hline $40-44$ & 2.16 & 2.15 & 2.00 & 1.90 & 2.04 \\
\hline All Women & 2.19 & 2.21 & 2.29 & 2.11 & 2.20 \\
\hline \multicolumn{6}{|c|}{ Ratio of Mean Intended Fertility to Mean Intended Fertility for All Women } \\
\hline Less than 20 & 1.12 & 0.93 & 1.07 & 1.08 & 1.05 \\
\hline $20-24$ & 1.04 & 1.10 & 1.19 & 1.12 & 1.11 \\
\hline $25-29$ & 1.05 & 1.04 & 1.12 & 1.09 & 1.07 \\
\hline $30-34$ & 1.00 & 0.97 & 1.07 & 1.06 & 1.02 \\
\hline 35 - 39 & 0.94 & 0.99 & 0.95 & 0.97 & 0.97 \\
\hline $40-44$ & 0.99 & 0.97 & 0.87 & 0.90 & 0.93 \\
\hline All Women & 1.00 & 1.00 & 1.00 & 1.00 & 1.00 \\
\hline
\end{tabular}

Age. There is a consistent, strong relationship between age and age-squared and intended fertility for the four General Social Survey datasets. The regression coefficient for age is positive and the coefficient for age-squared is negative. This means that intended fertility decreases for age but declines at a decreasing rate.

Marital Status. There are not statistically significant differences in intended fertility for women in married and common-low unions for three of the four General Social Survey datasets. The difference is statistically significant only in 1995, when women in common-law unions report about 0.5 more children than married women for their intended fertility. 
Number of Marriages. The reference category for number of marriages is women in their first marriage. Compared to the reference group, women who have not had a marital union (meaning, they must be in a common-law union) consistently report lower intended fertility. The differences are statistically significant in 1995 and 2001. Differences from women in their second or third or more marital union are inconsistent and generally not statistically significant.

Number of Common-Law Unions. The reference category for number of common-law unions is women who have never been in a common-law union. The results are inconsistent and usually not statistically significant. Overall, the regression estimates do not indicate that intended fertility is related to the number of common-law unions.

Employment. Compared to the reference category of "not in the labour force", working women consistently report lower intended fertility. The estimates for working women are statistically significant for 2001 and 2006 and, for all four surveys, working women report about 0.1 fewer children intended. Unemployed women do not report statistically significant differences in intended fertility.

In School. Women who are enrolled in school do not report statistically significant differences in intended fertility, compared to women who are not in school.

Educational attainment. Educational attainment is an important variable for the measurement of socioeconomic status. ${ }^{6}$ The regression results demonstrate, however, that there is not a statistically significant association with intended fertility.

Household Income. Household income does not have a statistically significant relationship with intended fertility.

Nativity. Canada-born women are the reference category for this variable. Intended fertility for immigrant women does not show statistically significant differences from that of Canada-born women.

Religious affiliation. Roman Catholic is the reference category for this variable. There are consistent differences for women who report no religious affiliation. Women with no religious affiliation report intended fertility that is .12 to .17 children less than Roman Catholic women; the estimates are statistically significant in 1990, 2001, and 2006. United Church women report lower intended fertility -.13 fewer 
children - than Roman Catholic women that is statistically significant only in 2006. Women who are other Protestant or other religious affiliations do not report consistent or statistically significant differences from Roman Catholic women.

Religious attendance. This variable displays consistent differences in intended fertility, comparing several categories of religious attendance to women who attend church at least weekly or more often, the reference category. All women who attend church less frequently report lower levels of intended fertility. Women who attend monthly report .02 to .14 fewer children. Women who attend a few times a year report .00 to .11 fewer children. Women who attend once a year report .06 to .30 fewer children. And women who do not attend at all report .09 to .20 fewer children. The estimates are usually statistically significant. The key difference seems to be between women who attend weekly or more often and other types of religious attendance. Women who attend monthly or a few times per year have roughly - averaging the regression coefficients for all years - about 0.1 fewer children. Women who seldom attend or not at all have roughly about 0.2 fewer children. Although the regression model does not explicitly test for an interaction between religious affiliation and religious attendance, additional analysis that is not shown here indicates that the relationship between religious attendance and intended fertility exists for each of the religious affiliations described above.

Home language. Compared to the reference category of women who speak English only at home, women who speak French only report statistically significant lower intended fertility only in 2001. Differences in intended fertility for women who speak other home languages are not consistent or statistically significant.

Multiple generation household. Women living in multiple generation households, compared to women in other types of households, consistently report much lower levels of intended fertility, about 0.4 to 0.5 fewer children. The differences are statistically significant in 1995, 2001 , and 2006.

Number of persons in the household. The number of persons in the household is consistently and strongly related to intended fertility. The selected sample includes households with at least two persons because all selected women have a partner present. Every additional person in the household is associated with an increase of 0.5 to 0.6 child in intended fertility. Although this variable reveals a noteworthy 
association between the number of persons and intended fertility, it should not be interpreted as a causal relationship. Women reporting a larger number for intended fertility may include some women who already have a large number of births. If women with a large number of births have many offspring living at home, this would affect intended fertility.

Province. Using Ontario as the reference category, differences in intended fertility for other provinces are not statistically significant. Overall, the regression analysis does not reveal that there are strong or consistent provincial differences in intended fertility, taking into account other factors.

\section{Decomposition of Differences}

Table 3 presents results for the decomposition of the change in intended fertility rates for four periods: 1990 to 1995,1995 to 2001,2001 to 2006 , and 1990 to $2006 .^{7}$ The first column shows the decomposition of difference of rates for 1990 to 1995 . The mean intended fertility rate was 2.20 in 1990, the beginning of the period, and 2.21 in 1995, the end of the period, or a change of 0.01 . If all variables in the regression analysis had their category weights change from their 1990 levels to their 1995 levels, mean intended fertility would have changed by -0.03 , decreasing from 2.20 to 2.17. This means that changes in the population composition of women between 1990 and 1995 would have led to a slight decrease in the observed mean intended fertility, if there had been no other changes.

The estimated regression coefficients (or "rates") also changed between 1990 and 1995. If the composition of the population had remained the same between 1990 and 1995 and the regression coefficients had changed, mean intended fertility would have increased by 0.04 . The interaction term for the decomposition of differences in rates for the 1990 to 1995 period is calculated as 0.00 .

Although there were negligible changes in mean intended fertility between 1990 and 1995, there were shifts in category weights and regression coefficients that largely counterbalanced each other. Nevertheless, the changes due to category weights and regression coefficients are not large and would not have led to substantial shifts in intended fertility.

The decomposition of differences in rates between 1995 and 2001 were similar, albeit somewhat larger, than between 1990 and 1995. Mean intended fertility decreased from 2.21 in 1995 to 2.20 in 2001 . If 
there had been changes in category weights, mean intended fertility would have decreased by 0.11 . If there had been changes in regression coefficients, mean intended fertility would have increased by $0.09-$ offsetting changes due to category weights. The interaction term is calculated as 0.01 .

Changes between 2001 and 2006 display a different pattern than in the previous two periods. Mean intended fertility declined by 0.08 , a considerably larger change than in previous periods. If there had been changes in category weights, mean intended fertility would have increased by 0.01 . Changes in regression coefficients were larger than changes due to category weights, with a 0.12 decrease due to changes in regression coefficients. The interaction term is calculated as 0.03 . Between 2001 and 2006, changes in category weights, or population composition, led to a slight increase in mean intended fertility. Changes due to regression coefficients, or rates, were counterbalanced by changes due to composition, and the overall mean intended fertility decreased by almost 0.08 during this period.

For the overall sixteen-year period, from 1990 to 2006, mean intended fertility decreased by 0.08 children, from 2.20 to $2.12 .{ }^{8}$ Because of changes in category weights, mean intended fertility would have decreased by 0.15 . This change was partially offset because changes in the regression coefficients were associated with an increase of 0.05 children. As in the three periods discussed above, the interaction term is small and calculated as 0.02 .

Two features of this decomposition of differences in rates stand out. First, there has been relatively little change over time in the mean intended fertility levels reported by Canadian women. Mean intended fertility has moved slightly up and down, but never by more than 0.1 children during the past sixteen years. Second, addressing the question of what would have happened if the Canadian population had not changed, it does not appear that changes due to population composition of women in married or common-law unions have had a marked association with changes in intended fertility. If the population composition had changed, as measured by differences in the category weights in the General Social Surveys between 1990 and 2006 - and no other changes had occurred - then the mean intended fertility would have decreased slightly by 0.15 .

It is impossible to allocate precisely the differences in rates due to changes in each variable in the regression equations. ${ }^{9}$ Table 4 shows the contribution of change in composition to the decomposition of differences in mean intended fertility. The first row of Appendix A2 (taken from Appendix A1) displays the total difference due to changes in 
Table 3

Decomposition of Change in Mean Intended Fertility Rates Canada: 1900-1995, 1995-2001, 2001-2006 and 1900-2006

\begin{tabular}{lcccc}
\hline & $\begin{array}{c}\mathbf{1 9 9 0 -} \\
\mathbf{1 9 9 5}\end{array}$ & $\begin{array}{c}\mathbf{1 9 9 5}- \\
\mathbf{2 0 0 1}\end{array}$ & $\begin{array}{c}\mathbf{2 0 0 1 -} \\
\mathbf{2 0 0 6}\end{array}$ & $\begin{array}{c}\mathbf{1 9 9 0 -} \\
\mathbf{2 0 0 6}\end{array}$ \\
\hline & & & & \\
Mean Intended Fertility: & & & & \\
& & & & \\
At beginning of period & 2.20 & 2.21 & 2.20 & 2.20 \\
At end of period & 2.21 & 2.20 & 2.12 & 2.12 \\
Change during period & 0.01 & -0.01 & -0.08 & -0.08 \\
& & & & \\
Difference due to: & & & & \\
Change in category weights & -0.03 & -0.11 & 0.01 & -0.15 \\
Change in Regression & 0.04 & 0.09 & -0.12 & 0.05 \\
Coefficients & & & & \\
Interaction term & 0.00 & 0.01 & 0.03 & 0.02 \\
& & & & \\
\hline
\end{tabular}

Note: The mean intended fertility in Table 3 is derived from the predicted intended fertility from each of the four regression equations as reported in the Appendix Tables A1, A2, A3 and A4 holding all variables constant at the mean for continuous variables or at the observed proportions for categorieal variables. The mean intended fertility in Table 1 differs slightly from the values in Table 1 and other descriptive statistics because the regression equations include slightly different samples.

composition: -0.03 for 1990 to $1995,-0.11$ for 1995 to $2001,0.01$ for 2001 to 2006, and -0.15 for the overall 1990 to 2006 period. Most of the changes in composition attributable to each variable are consistent, albeit some changes are modest. The most noticeable effect of shifts in population composition is that the ageing of the female population would have led to decreases in intended fertility, a decline of 0.09 for the 1990 to 2006 period. For 1990 to 2006, the effect of changes in category weights shows changes of 0.03 or less for the other variables. Changes in mean household size would have decreased mean intended fertility by 0.03 . Changes in mean number of marriages or category weights for educational attainment would have increased mean intended fertility by 0.02. Changes in other socioeconomic status factors, social factors, household factors, and spatial factors would not have led to sizeable 
changes in intended fertility because the effects on changes in mean intended fertility between 1990 and 2006 are .01 or less.

Changes in the estimated regression coefficients, or rates, affected the overall change in mean intended fertility (see Table 5). Even if there had been no change in population composition, the relationship between a set of explanatory variables and intended fertility did not remain constant. The relationship between several variables and intended fertility altered during the 1990 to 2006 period, although not always in consistent ways. The relationship between age and intended fertility changed - becoming more positive between 1990 and 1995, more negative between 1995 and 2001, more positive between 2001 and 2006, and generally more negative during the overall period 1990 to 2006 . Had there been no other changes, in category weights or regression coefficients for other variables, changes in the regression coefficients for age and age-squared would have decreased mean intended fertility by about 0.08 between 1990 and 2006. Changes in the regression coefficients for several other variables - including the number of common-law unions, employment, and nativity - would have decreased mean intended fertility between 1990 and 2006. Education, household size, and province of residence, however, had the opposite effect: changes in the regression coefficients for these three variables would have increased mean intended fertility - by $0.34,0.28$, and 0.13 , respectively - if there had been no other changes between 1990 and 2006. Changes in the regression coefficients for other variables had modest effects on the contribution of changes due to rates between 1990 and 2006.

Comparing the differences due to change in category weights and change in regression coefficients, it appears that changes in intended fertility due to change in category weights for specific variables have been generally modest. Changes in number of marriages and education would have increased intended fertility slightly. But these positive effects have been largely counter balanced by the negative effects of changes in age and household size. Differences due to changes in regression coefficients have been somewhat larger than those due to changes in category weights. Nevertheless, the overall effect of changes for specific variables, whether due to changes in category weights or regression coefficients, has been limited to shifts of 0.1 child or less to mean intended fertility, the two exceptions being increases in mean intended fertility that were due to changes in regression coefficients for education and household size, 0.34 and 0.28 , respectively, between 1990 to 2006 . 
Table 4

Contribution of Change in Category Weights

to Decomposition of Differences in Mean Intended Fertility Rates for Canada: 1990-1995, 1995-2001, 2001-2006, and 1990-2006

\begin{tabular}{|c|c|c|c|c|}
\hline Variable & $\begin{array}{c}1990 \text { to } \\
1995\end{array}$ & $\begin{array}{c}1995 \text { to } \\
2001\end{array}$ & $\begin{array}{c}2001 \text { to } \\
2006\end{array}$ & $\begin{array}{c}1990 \text { to } \\
2006\end{array}$ \\
\hline Total Difference Due to Category Weights ${ }^{1}$ & -0.03 & -0.11 & 0.01 & -0.15 \\
\hline \multicolumn{5}{|l|}{ Difference Due to Each Variable } \\
\hline \multicolumn{5}{|l|}{ Demographic Factors } \\
\hline $\mathrm{Age}^{2}$ & -0.03 & -0.05 & -0.01 & -0.09 \\
\hline Marital Status & 0.01 & 0.00 & 0.00 & 0.01 \\
\hline Number of Marriages & -0.02 & -0.01 & -0.01 & 0.02 \\
\hline Number of Common-Law Unions & -0.01 & 0.00 & 0.00 & -0.01 \\
\hline \multicolumn{5}{|l|}{ Socioeconomic Status Factors } \\
\hline Employment & 0.00 & -0.01 & 0.00 & 0.00 \\
\hline In School & 0.00 & 0.00 & 0.00 & 0.00 \\
\hline Education & 0.00 & 0.02 & 0.00 & 0.02 \\
\hline Household Income ${ }^{2}$ & 0.00 & -0.01 & 0.01 & -0.01 \\
\hline \multicolumn{5}{|l|}{ Social Factors } \\
\hline Nativity & 0.00 & 0.00 & 0.00 & 0.00 \\
\hline Religious Affiliation & -0.01 & 0.00 & 0.00 & -0.01 \\
\hline Religious Attendance & 0.00 & 0.00 & 0.00 & -0.01 \\
\hline Home Language & 0.00 & 0.00 & 0.00 & 0.00 \\
\hline \multicolumn{5}{|l|}{ Household Factors } \\
\hline Multiple Generation Household & 0.00 & -0.01 & 0.00 & -0.01 \\
\hline Household Size & 0.01 & -0.05 & 0.02 & -0.03 \\
\hline \multicolumn{5}{|l|}{ Spatial Factors } \\
\hline Province & 0.00 & 0.00 & 0.00 & 0.00 \\
\hline
\end{tabular}

\footnotetext{
${ }^{1}$ The sum of each variable contribution does not necessarily add to the total difference because of rounding because the interaction term possibly includes some of the variable differences due to either composition or rates.

${ }^{2}$ This variable includes two terms: the observed value of the variable and the square of the variable.
} 
Table 5

Contribution of Change in Regression Coefficients

to Decomposition of Differences in Mean Intended Fertility Rates for Canada: 1990-1995, 1995-2001, 2001-2006, and 1990-2006

\begin{tabular}{|c|c|c|c|c|}
\hline Variable & $\begin{array}{c}1990 \text { to } \\
1995\end{array}$ & $\begin{array}{c}1995 \text { to } \\
2001\end{array}$ & $\begin{array}{c}2001 \text { to } \\
2006\end{array}$ & $\begin{array}{c}1990 \text { to } \\
2006\end{array}$ \\
\hline Total Difference Due to Regression Coefficients ${ }^{1}$ & 0.04 & 0.09 & -0.12 & 0.05 \\
\hline \multicolumn{5}{|l|}{ Difference Due to Each Variable } \\
\hline \multicolumn{5}{|l|}{ Demographic Factors } \\
\hline $\mathrm{Age}^{2}$ & 0.63 & -0.95 & 0.24 & -0.08 \\
\hline Marital Status & 0.12 & -0.12 & 0.01 & 0.04 \\
\hline Number of Marriages & -0.05 & 0.07 & 0.01 & 0.01 \\
\hline Number of Common-Law Unions & -0.07 & 0.07 & -0.05 & -0.07 \\
\hline \multicolumn{5}{|l|}{ Socioeconomic Status Factors } \\
\hline Employment & -0.01 & -0.03 & 0.03 & -0.02 \\
\hline In School & 0.00 & -0.01 & 0.02 & 0.00 \\
\hline Education & 0.54 & -0.25 & 0.03 & 0.34 \\
\hline Household Income ${ }^{2}$ & -0.01 & 0.08 & -0.01 & 0.07 \\
\hline \multicolumn{5}{|l|}{ Social Factors } \\
\hline Nativity & -0.01 & 0.02 & -0.04 & -0.02 \\
\hline Religious Affiliation & 0.01 & 0.02 & 0.02 & 0.06 \\
\hline Religious Attendance & 0.07 & -0.05 & 0.01 & 0.03 \\
\hline Home Language & -0.01 & -0.06 & 0.07 & 0.01 \\
\hline \multicolumn{5}{|l|}{ Household Factors } \\
\hline Multiple Generation Household & 0.00 & 0.00 & 0.00 & 0.00 \\
\hline Household Size & 0.34 & -0.22 & 0.17 & 0.28 \\
\hline \multicolumn{5}{|l|}{ Spatial Factors } \\
\hline Province & 0.01 & 0.13 & -0.02 & 0.13 \\
\hline
\end{tabular}

${ }^{1}$ The sum of each variable contribution does not necessarily add to the total difference because of rounding because the interaction term possibly includes some of the variable differences due to either composition or rates.

${ }^{2}$ This variable includes two terms: the observed value of the variable and the square of the variable. 


\section{Discussion and Implications}

The key finding from this study is the remarkable stability of fertility intentions reported by Canadian women. The answer to the question posed in the paper's title appears to be "no change". Descriptive trend analysis shows that fertility intentions have varied only slightly over time. Overall, fertility intentions increased slightly from 1990 to 2001 and decreased slightly from 2001 to 2006 . Canada's stable aggregate fertility intentions are similar to trends reported in other countries, for example, the United States (Peterson 1995).

After investigating the role of changes in population composition between each of the survey periods, it appears that change in the composition of women in the childbearing years had a modest influence on changes in fertility intentions during the 1990 to 2006 period, especially from the 1995 to the 2001 survey. For the overall period, between 1990 and 2006, mean fertility intentions declined by just 0.08 . Shifts in the composition of the female population $\square$ (as measured by changes in the category weights for selected explanatory variables) would have decreased mean fertility intentions by 0.15 . However, changes in the relationship between explanatory variables and fertility intentions (as measured by regression coefficients) partially counterbalanced composition shifts and would have increased mean fertility intentions by 0.05 . If the effect of changes due to regression coefficients had not counterbalanced the effect of changes due to population composition, actual fertility intentions would have decreased by about 0.15 , a noticeably larger decrease in mean fertility intentions than actually observed.

This paper started with a discussion that fertility intentions could be usefully viewed as a mediating variable for understanding fertility behaviour (Schoen et al. 1997; Schoen et al. 1999). Although Canadian women's fertility intentions have been above replacement-level fertility during 1990 to 2006, fertility behaviour - as evidenced by such measures as the total fertility rate - have been below replacement-level fertility. Actual completed fertility is below desired fertility in many countries, including Canada. ${ }^{10}$ What accounts for differences between intended and achieved fertility? There are many possible factors and currently available empirical research is only suggestive since data over a woman's life-course are generally unavailable to track her reproductive career starting with intended fertility to eventual completed fertility.

One potential factor is infecundity, either because a woman or her partner or both are unable to have children or may have delayed childbearing to an older age when it becomes difficult to have children. Second, some women may want to have children but do not find a 
suitable partner with whom to have children. This type of "social celibacy" means that some women are not in a sexual union that is productive of childbearing and may find themselves either childless or with fewer children than desired by the end of their childbearing years.

Third, researchers have also speculated that the combination of employment careers and marital disruption has a retardant effect on childbearing, reducing achieved fertility relative to desired fertility (Bernhardt 1993; Quesnel-Vallée and Morgan 2003). Finally, one cannot discount the powerful role of social norms that influence expressions of intended fertility (Quesnel-Vallée and Morgan 2003; Schoen et al. 1997). In many low fertility countries, the preference for two children remains a strong social norm but as women, and their partners, progress through life, conditions and events including the pursuit of education and employment, particularly among women, often contribute to an underachievement of expressed fertility intentions. Regardless of the factors that influence fertility intentions and behaviour, and how the different factors operate, the evidence on completed fertility suggests that in most developed countries, there continues to be a gap between desired and actual fertility.

In addition to factors that affect the difference between desired and actual fertility, there is an important difference between measures of period fertility and cohort fertility. Many policymakers focus on the total fertility rate, an indication of the number of children a hypothetical woman would have under the age-specific fertility rates observed in a particular year. One common interpretation of the total fertility rate is in terms of "replacement-level fertility," where it is noted that the replacement-level total fertility rate for developed countries is 2.1 children. There is a complex relationship between annual period rates such as the total fertility rate and cohort fertility. In fact, completed fertility for Canadian birth cohorts of women are higher, about 0.2 child in recent years, than the total fertility rate. The total fertility rate in Canada, as in several European countries, has been distorted by shifts in the age of childbearing. As Canadian women have children at older ages, this spreads childbearing out over a longer period of time, reducing the observed number of births in a particular year. ${ }^{11}$ As a result, the observed total fertility rate in Canada has been about 0.2 child less than implied by cohort fertility patterns.

Fertility levels have been moderately low in Canada for several decades. While Canadian fertility has not been as low as in some southern and eastern European countries, where the total fertility rate has persisted at levels of 1.3 or below, it has remained below replacementlevel for quite long. The study of fertility postponement has been a topic of active research for the lowest-low fertility countries of Europe. These 
countries, which are characterized by total fertility rates of 1.3 or lower, are notable for two demographic features: fairly low completed fertility and increasing ages at onset of childbearing. While Canada's total fertility is not below 1.3, there have been changes in mean age at first birth that are similar to the lowest-low fertility populations of southern and eastern Europe. Italy and Spain were the first southern and eastern European countries where the mean age of first birth began to steadily increase, starting around 1980. By the mid-1990s, most southern and eastern European populations were also seeing steady increases in mean maternal age. Although it is difficult to note a precise year, the mean age at first birth has been increasing in Canada since about 1980. If we compare the mean age at first birth in Canada with southern and eastern European countries in 1999 (Kohler et al. 2002: Table 1), Canada had a very high mean age ( 26.9 years) that was exceeded only by Greece, Italy, and Spain. Since 1999, the mean age at first birth in Canada has continued to climb, advancing to 28 years in 2005 .

Studies of southern and eastern European populations suggest that there is a 3 to 5 percent decrease in completed fertility associated with each one-year increase in the onset of motherhood. Because the mean age of first birth increased 2.2 years from 1990 to 2005 in Canada, this suggests a longer-term reduction of about 0.1 to 0.2 in completed fertility. It would be useful to have additional research on the effect of the postponement of fertility on longer-term completed fertility in Canada. But, available aggregate evidence from southern and eastern European countries gives little reason to expect that completed fertility rates in Canada will rise, owing to the tempo distortion caused by the postponement of fertility. Once the mean age of first birth ceases to increase in Canada, then period fertility rates will increase to become similar to completed fertility levels, all other factors being equal.

There has been a modest upturn in total fertility rates in recent years in several European countries, such as France and the United Kingdom, as well as in Canada and the United States. Although the increases have been modest - usually gains of 0.1 to 0.2 in the total fertility rates - they have occurred in many European countries, Canada, and the United States. It is still too early to know if these increases during recent years are a reversal of lower fertility levels or simply a fluctuation in total fertility rates. If they represent a longer-term shift upwards in fertility behaviour, they raise questions about their causes and have important implications for population growth.

If research from low-fertility countries in Europe suggests that it is unlikely that Canada's fertility rates will increase in the future, how can research on fertility intentions contribute to thinking about future trends in fertility in Canada? This paper's main finding is the remarkable 
stability of fertility intentions among Canadian women over the sixteenyear period from 1990 to 2006 . It appears that while fertility rates have been declining and Canadian women have been postponing births, their thoughts about intended fertility have not changed much and have remained higher than actual fertility as measured by the total fertility rate. There are several implications following from our findings. First, social norms about family size (around two children) are remarkably resilient, in spite of actual behaviour. Second, the higher intended fertility expressed by Canadian women opens the door to potential policy changes from government and employers that could facilitate the fulfillment of desired fertility by many Canadian women, which could also ameliorate concerns over persistently low fertility. Finally, it is possible that future research on fertility intentions may show a closing of the gap with realized fertility as ideas and behaviour become more consistent.

\section{Acknowledgement}

Responsibility for any errors rests with the authors.

\section{End Notes}

1. The Fertility and Family Survey project was coordinated by the U.N. Economic Commission for Europe (UNECE). Canada's participation in this international project included the data collection and tabulation of the 1990 and 1995 General Social Surveys.

2. Analysis of both women and men would complicate and expand the analysis and confuse the interpretation of results for women and men combined. Furthermore, our analysis found that fertility intentions of men and women in the four General Social Surveys were virtually identical. There are only modest differences in mean intended fertility for males and females who are in married or common-law unions (see Edmonston, Lee, and $\mathrm{Wu} 2008$ ). The differences are less than 0.1 child in each of the four General Social Survey years. In 1990, mean intended fertility for males was 0.05 children greater than for females but in the other three years - 1995, 2001, and 2006 - mean intended fertility for females was slightly higher than for males $-0.04,0.03$, and 0.07 , respectively. Results from analysis of the age-period-cohort 
model that presents separate estimates for men and women (described in Edmonston, Lee, and $\mathrm{Wu} 2008$ ) find a modest difference in the fertility intentions between men and women just 0.07 child higher for women, after controlling for all other explanatory variables in the model.

3. It is unclear why a higher proportion of women in 2001 report intentions to have five or more children. The 2001 survey includes 204 women reporting that they intend to have five more children, so the higher proportion is not due to a very small sample size. In analysis not reported here, we examined the characteristics of women in all four General Social Survey datasets who intend to have five or more children. We did not notice special differences between the women in the four surveys.

4. The ability to have children after age 30 would be affected by the likelihood of permanent sterility, the onset of either anovulatory cycles or diseases associated with the cessation of ovulation, and voluntary sterilization. Although infecundity and subfecundity increases after about age 30, we do not know of research that makes specific estimates of probabilities for Canadian women.

5. Because the sample size for the regression equations are not necessarily the same as for the calculation of descriptive statistics, the overall mean predicted fertility for the regression results may differ (slightly) from that shown in the descriptive trend analysis. Missing cases for selected variables affect both descriptive and multivariate statistics and imply that comparisons of mean intended fertility may differ slightly for some tables.

6. We include a woman's educational attainment in the regression analysis rather than occupation. Unlike occupation, which is available only for women who are in the labour force, educational attainment is measured for all women.

7. The mean intended fertility in Table 3 is derived from the predicted intended fertility from each of the four regression equations - reported in Appendix Tables A1, A2, A3 and A4 holding all variables constant at the mean for continuous variables or at the observed proportions for categorical variables. The mean intended fertility in Table 3 differs slightly from the values shown in Tables 1 and 2 because the regression equations include slightly different samples. 
8. Although changes for two sequential periods are not strictly additive, changes for periods such as 1990 to 2001 can be estimated by adding together the changes for 1990-1995 and 1995-2001.

9. To calculate these effects, we change either the category weights or the regression coefficients for each variable, one by one. We do not calculate interaction terms because this would require making assumptions about the possible correlations between changes in pairs and combinations of variables. Thus, there is some modest inaccuracy in the allocation of effects to each variable. Because of these inaccuracies, the sum of the effects, for category weights and regression coefficients, do not necessarily add precisely to the observed total.

10. The correspondence between intended and achieved fertility may be closer when underachievers (those who have fewer children than intended) and overachievers (those who have more than intended) roughly balance each other (Quesnel-Vallée and Morgan 2003). Schoen at al (1997) also discuss the role of children as social capital in influencing childbearing in low fertility countries, implying that the gap between higher intended and lower actual fertility may be smaller for individuals and societies when children are perceived as representing valuable social capital. than earlier cohorts, these increases are not sufficient to counterbalance lower fertility in younger ages due to delayed childbearing.

11. Although women in recent cohorts have higher fertility in their thirties than earlier cohorts, these increases are not sufficient to counterbalance lower fertility in younger ages due to delayed childbearing. 


\section{References}

Baker, M. 1994. Family and population policy in Quebec: Implications for women. Canadian Journal of Women and the Law 7: 116-132.

Beaujot, R. 1994. The family and demographic change in Canada: Economic and cultural interpretations and solutions, in Perspectives on Canada's Population, edited by Frank Trovato and Carl F. Grindstaff. Ontario: Oxford University Press, pp. 248259.

Beaujot, R. and A. Muhammad. 2006. Transformed families and the basis for childbearing, in Canada's Changing Families, edited by Kevin McQuillan and Zenaida Ravanera. Toronto: University of Toronto Press, pp. 15-48.

Bélanger, A. and S. Gilbert. 2005. The Fertility of Immigrant Women and Their Canada-born Daughters, Part II, in Report on the Demographic Situation in Canada, 2002. Ottawa: Demography Division, Statistics Canada.

Bernhardt, E. M. 1993. Fertility and employment. European Sociological Review 9: 25-42.

Bongaarts, J. 2001. Fertility and reproduction preferences in posttransitional societies: Supplement on global fertility transition. Population and Development Review 27: 260-281.

Bongaarts, J. 2001. The end of the fertility transition in the developed world. Population and Development Review 28: 419-443.

Brewster, K. L. and R. R. Rindfuss. 2000. Fertility and women's employment in industrialized nations. Annual Review of Sociology 26: 271-296.

Das[Gupta, P. 1993. Standardization and decomposition of rates from cross-classified data. Genus 50 (July-December): 171-196.

Demeny, P. 1997. Replacement level fertility: The implausible endpoint of the demographic transition, in The Continuing Demographic Transition, edited by Gavin W. Jones, et al. Oxford: Clarendon Press, pp. 94-110. 
Demeny, P. 2001. Population policy dilemmas in Europe at the dawn of the twenty-first century. Population and Development Review 29: 1-28.

Diggle, P. J., K-Y. Liang, and S. L. Zeger. 1984. Analysis of Longitudinal Data. Oxford: Clarendon Press.

Dupuis, D. 1997. What influences people's plans to have children? Canadian Social Trends, No. 48.

Edmonston, B., S. M. Lee, and Z. Wu. 2008. Fertility Intentions in Canada, 1990-2006. Final Report submitted to Human Resources and Social Development Canada. Ottawa: Human Resources and Social Development Canada.

Freedman, R., L. C. Coombs, and L. Bumpass. 1995. Stability and change in expectations about family size. Demography 2: 250-275.

Goldstein, J. R., W. Lutz, and M. R. Testa. 2003. The emergence of subreplacement family size ideals in Europe. Population and Development Review 22: 479-496.

Hagewen, K. J. and S. P. Morgan. 2005. Intended and ideal family size in the United States, 1970-2002. Population and Development Review 31: 507-527.

Hakim, C. 2003. A new approach to explaining fertility patterns: Preference theory. Population and Development Review 29: 349-374.

Kitagawa, E. 1955. Components of difference between two rates. Journal of the American Statistical Association 50 (December): 1168-1194.

Kohler, H.-P., F. C. Billari, J. A. Ortega. 2001. The Emergence of lowest-low fertility in Europe during the 1990s. Population and Development Review 28: 641-680.

McDonald, P. 2000. Gender equity in theories of fertility transition. Population and Development Review 26: 427-439. 
Moffitt, R. 2001. Remarks on the analysis of causal relationship in population research. Demography 42: 91-108.

Morgan, S. P. 2003. Is low fertility a twenty-first century demographic crisis? Demography 40: 589-603.

Peterson, L. S. 1995. Birth Expectations of Women in the United States: 1973-1989. National Center for Health Statistics, Vital Health Statistics Series 23 (17).

Quesnel-Vallée, A. and S. P. Morgan. 2003. Missing the target? Correspondence of fertility intentions and behavior in the United States. Population Research and Policy Review 22: 497-525.

Ram, B. 1994. Family formation, in Perspectives on Canada's Population, edited by Frank Trovato and Carl F. Grindstaff. Ontario: Oxford University Press, pp. 236-247.

Romaniuc, A. 1993. Fertility in Canada: Retrospective and prospective, in Perspectives on Canada's Population, edited by Frank Trovato and Carl F. Grindstaff. Ontario: Oxford University Press, pp. 214-230.

Rubin, D. 1974. Estimating causal effects of treatments in randomized and nonrandomized studies. Journal of Educational Psychology 66: 688-701.

Ryder, N. B. 1983. Cohort and period measures of changing fertility, in Determinants of Fertility in Developing Countries, edited by Rodolfo A. Bulatao and Ronald D. Lee. New York: Academic Press, pp. 737-756.

Schoen, R., Y. J. Kim, C. A. Nathanson, J. Fields, and N. M. Astone. 1997. Why do Americans want children. Population and Development Review 23: 333-358.

Schoen, R., N. M. Astone, Y. J. Kim, and C. A. Nathanson. 1999. Do fertility intentions affect fertility behavior? Journal of Marriage and the Family 61: 790-799.

Statistics Canada. 1992. General Social Survey, Family and Friends 1990. Public Use Microdata File Documentation and User's Guide. Ottawa: Statistics Canada. 
Statistics Canada. 1997. General Social Survey, Cycle 10: The Family. Public Use Microdata File Documentation and User's Guide. Ottawa: Statistics Canada.

Statistics Canada. 2003. General Social Survey, 2001, Cycle 15: Family History. Public Use Microdata File Documentation and User's Guide. Ottawa: Statistics Canada.

Statistics Canada. 2008a. General Social Survey, Cycle 20: Family Transitions (2006). Public Use Microdata File Documentation and User's Guide. Ottawa: Statistics Canada.

Statistics Canada. 2008b. Report on the Demographic Situation: 2005 and 2006. Catalogue no. 91-20-X. Ottawa: Statistics Canada. 
Barry Edmonston, Sharon M. Lee and Zheng Wu

Appendix A-1

Regression Analysis for Mean Intended Fertility, Women in Married

or Common-Law Unions, Aged 15 to 44 Years for Canada: 1990

\begin{tabular}{|c|c|c|c|c|}
\hline Explanatory Variable & Coefficient & $\begin{array}{l}\text { Standard } \\
\text { Error }\end{array}$ & t-value & $\begin{array}{c}\text { Predicted Mean } \\
\text { Intended Fertility } \\
\text { (Holding All Other } \\
\text { Variables at } \\
\text { Observed Mean) }\end{array}$ \\
\hline Constant & 5.4487 & 0.5280 & 10.15 & \\
\hline \multicolumn{5}{|l|}{ Demographic Factors } \\
\hline \multicolumn{5}{|l|}{ Age of Respondent } \\
\hline Age & -0.2250 & 0.0320 & -6.70 & * \\
\hline Age-Squared & 0.0027 & 0.0000 & 5.25 & * \\
\hline \multicolumn{5}{|l|}{ Marital Status } \\
\hline Married (Reference Category) & & & & 2.20 \\
\hline Common-Law & -0.0816 & 0.1240 & -0.83 & 2.12 \\
\hline \multicolumn{5}{|l|}{ Number of Marriages } \\
\hline 0 Marriages & -0.1311 & 0.1090 & -1.39 & 2.07 \\
\hline 1 Marriage (Reference Category) & & & & 2.20 \\
\hline 2 Marriages & -0.0292 & 0.0790 & -1.43 & 2.17 \\
\hline 3+ Marriages & 0.2700 & 0.3000 & 1.29 & 2.47 \\
\hline \multicolumn{5}{|l|}{ Number of Common-Law Unions } \\
\hline 0 Unions Reference Category) & & & & 2.20 \\
\hline 1 Union & 0.1231 & 0.0950 & 0.61 & 2.32 \\
\hline 2 Unions & 0.1925 & 0.1440 & 1.20 & 2.39 \\
\hline 3+ Unions & 0.1909 & 0.5170 & 0.28 & 2.39 \\
\hline \multicolumn{5}{|l|}{ Socioeconomic Status Factors } \\
\hline \multicolumn{5}{|l|}{ Employment } \\
\hline Working & -0.0768 & 0.0460 & -0.08 & 2.12 \\
\hline Unemployed & -0.1644 & 0.1380 & -1.19 & 2.03 \\
\hline Category) & & & & 2.20 \\
\hline In School & & & & \\
\hline Not in School (Reference Category) & & & & 2.20 \\
\hline In School & -0.0175 & 0.1100 & -0.59 & 2.18 \\
\hline \multicolumn{5}{|l|}{ Education } \\
\hline Elementary or Less (Reference Category) & & & & 2.20 \\
\hline Some Secondary & -0.2129 & 0.1440 & -1.18 & 1.99 \\
\hline Secondary Graduate & -0.2604 & 0.1430 & -1.55 & 1.94 \\
\hline Some Trade or Technical & -0.0841 & 0.1550 & -0.48 & 2.11 \\
\hline Some College & -0.1303 & 0.1510 & -0.93 & 2.07 \\
\hline Some University & -0.1913 & 0.1550 & -1.98 & 2.01 \\
\hline Trade or Technical Diploma & -0.3335 & 0.1470 & -1.81 & 1.87 \\
\hline College Diploma & -0.0987 & 0.1480 & -0.56 & 2.10 \\
\hline Bachelor's Degree and More & -0.1375 & 0.1470 & -0.67 & 2.06 \\
\hline \multicolumn{5}{|l|}{$\begin{array}{l}\text { Household Income in Constant Dollars } \\
\text { (in 100,000s) }\end{array}$} \\
\hline Household Income & -0.2925 & 0.2522 & -1.16 & * \\
\hline Household Income-Squared & 0.9071 & 0.9351 & 0.97 & * \\
\hline
\end{tabular}


Fertility Intentions in Canada: Change or No Change?

Appendix A-1 (Continued)

\begin{tabular}{|c|c|c|c|c|}
\hline Explanatory Variable & Coefficient & $\begin{array}{c}\text { Standard } \\
\text { Error }\end{array}$ & t-value & $\begin{array}{c}\text { Predicted Mean } \\
\text { Intended Fertility } \\
\text { (Holding All Other } \\
\text { Variables at } \\
\text { Observed Mean) }\end{array}$ \\
\hline \multicolumn{5}{|l|}{ Social Factors } \\
\hline \multicolumn{5}{|l|}{ Nativity } \\
\hline Canada-Born (Reference Category) & & & & 2.20 \\
\hline Foreign-Born & 0.0383 & 0.0660 & 0.36 & 2.24 \\
\hline \multicolumn{5}{|l|}{ Religious Affiliation } \\
\hline No Religion & -0.1722 & 0.0820 & -2.63 & 2.03 \\
\hline Roman Catholic (Reference Category) & & & & 2.20 \\
\hline United Church & -0.0156 & 0.0640 & -1.69 & 2.18 \\
\hline Other Protestant & -0.0276 & 0.0330 & -1.61 & 2.17 \\
\hline Other Religion & -0.2668 & 0.1100 & -1.73 & 1.93 \\
\hline \multicolumn{5}{|l|}{ Religious Attendance } \\
\hline Weekly or More (Reference Category) & & & & 2.20 \\
\hline Monthly or More & -0.0764 & 0.0640 & -1.58 & 2.12 \\
\hline Few Times a Year & -0.0842 & 0.0620 & -2.61 & 2.11 \\
\hline At Least Once a Year & -0.2994 & 0.0760 & -4.41 & 1.90 \\
\hline Not at All & -0.2044 & 0.0620 & -3.39 & 1.99 \\
\hline \multicolumn{5}{|l|}{ Home Language } \\
\hline English Only (Reference Category) & & & & 2.20 \\
\hline French Only & -0.0885 & 0.0920 & -1.84 & 2.11 \\
\hline Other Home Language & 0.0153 & 0.0940 & 0.74 & 2.21 \\
\hline \multicolumn{5}{|l|}{ Household Factors } \\
\hline \multicolumn{5}{|l|}{ Multiple Generation Household } \\
\hline Category) & & & & 2.20 \\
\hline Multiple Generation & -0.4204 & 0.1770 & -0.93 & 1.78 \\
\hline Number of Persons in Household & 0.4954 & 0.0210 & 22.29 & * \\
\hline \multicolumn{5}{|l|}{ Spatial Factors } \\
\hline \multicolumn{5}{|l|}{ Province } \\
\hline Newfoundland and Labrador & 0.0522 & 0.0900 & 0.38 & 2.25 \\
\hline Prince Edward Island & 0.1565 & 0.1570 & 0.60 & 2.36 \\
\hline Nova Scotia & -0.1246 & 0.0930 & -1.31 & 2.07 \\
\hline New Brunswick & -0.0646 & 0.0970 & -1.04 & 2.13 \\
\hline Quebec & -0.1496 & 0.0930 & -0.86 & 2.05 \\
\hline Ontario (Reference Category) & & & & 2.20 \\
\hline Manitoba & -0.1161 & 0.0880 & -1.26 & 2.08 \\
\hline Saskatchewan & -0.0894 & 0.0900 & -0.50 & 2.11 \\
\hline Alberta & 0.0444 & 0.0720 & 0.61 & 2.24 \\
\hline British Columbia & -0.1710 & 0.0750 & -1.93 & 2.03 \\
\hline \multicolumn{5}{|l|}{ Model Summary } \\
\hline R-Squared & 0.2913 & & & \\
\hline Standard Error of the Estimates & 0.8676 & & & \\
\hline Weighted Number of Observations & $3,596,543$ & & & \\
\hline Unweighted Number of Observations & 2,104 & & & \\
\hline
\end{tabular}

"See text for interpretation of the predicted mean fertility for continuous variables. 
Barry Edmonston, Sharon M. Lee and Zheng Wu

Appendix A-2

Regression Analysis for Mean Intended Fertility, Women in Married

or Common-Law Unions, Aged 15 to 44 Years for Canada: 1995

\begin{tabular}{|c|c|c|c|c|}
\hline Explanatory Variable & Coefficient & $\begin{array}{l}\text { Standard } \\
\text { Error }\end{array}$ & t-value & $\begin{array}{c}\text { Predicted Mean } \\
\text { Intended Fertility } \\
\text { (Holding All Other } \\
\text { Variables at } \\
\text { Observed Mean) } \\
\end{array}$ \\
\hline Constant & 3.9464 & 0.5660 & 8.40 & \\
\hline \multicolumn{5}{|l|}{ Demographic Factors } \\
\hline \multicolumn{5}{|l|}{ Age of Respondent } \\
\hline Age & -0.1874 & 0.0340 & -6.37 & * \\
\hline Age-Squared & 0.0022 & 0.0010 & 5.15 & $*$ \\
\hline \multicolumn{5}{|l|}{ Marital Status } \\
\hline Married (Reference Category) & & & & 2.12 \\
\hline Common-Law & 0.4952 & 0.1350 & 2.86 & 2.62 \\
\hline \multicolumn{5}{|l|}{ Number of Marriages } \\
\hline 0 Marriages & -0.4597 & 0.1190 & -3.32 & 1.66 \\
\hline 1 Marriage (Reference Category) & & & & 2.12 \\
\hline 2 Marriages & 0.0020 & 0.0870 & 0.53 & 2.12 \\
\hline 3+ Marriages & -0.1694 & 0.8500 & -0.29 & 1.95 \\
\hline \multicolumn{5}{|l|}{ Number of Common-Law Unions } \\
\hline 0 Unions Reference Category) & & & & 2.12 \\
\hline 1 Union & -0.1190 & 0.0900 & -1.13 & 2.00 \\
\hline 2 Unions & -0.2015 & 0.1320 & -1.95 & 1.92 \\
\hline 3+ Unions & -0.2089 & 0.2580 & -0.35 & 1.91 \\
\hline \multicolumn{5}{|l|}{ Socioeconomic Status Factors } \\
\hline \multicolumn{5}{|l|}{ Employment } \\
\hline Working & -0.1080 & 0.0500 & -1.92 & 2.01 \\
\hline Unemployed & 0.2034 & 0.1600 & 1.10 & 2.33 \\
\hline \multicolumn{5}{|l|}{ Not in the Labour Force (Reference } \\
\hline Category & & & & 2.12 \\
\hline \multicolumn{5}{|l|}{ In School } \\
\hline Not in School (Reference Category) & & & & 2.20 \\
\hline In School & -0.0479 & 0.1110 & 0.51 & 2.07 \\
\hline \multicolumn{5}{|l|}{ Education } \\
\hline Elementary or Less (Reference Category) & & & & 2.12 \\
\hline Some Secondary & 0.3704 & 0.1740 & 1.48 & 2.49 \\
\hline Secondary Graduate & 0.2502 & 0.1710 & 0.63 & 2.37 \\
\hline Some Trade or Technical & 0.2553 & 0.1990 & 0.83 & 2.38 \\
\hline Some College & 0.5382 & 0.1870 & 1.96 & 2.66 \\
\hline Some University & 0.3439 & 0.1860 & 1.14 & 2.47 \\
\hline Trade or Technical Diploma & 0.3280 & 0.1770 & 1.14 & 2.45 \\
\hline College Diploma & 0.3864 & 0.1730 & 1.39 & 2.51 \\
\hline Bachelor's Degree and More & 0.4381 & 0.1740 & 1.86 & 2.56 \\
\hline \multicolumn{5}{|l|}{$\begin{array}{l}\text { Household Income in Constant Dollars (in } \\
100,000 \text { s) }\end{array}$} \\
\hline Household Income & -0.3220 & 0.2051 & -1.57 & * \\
\hline Household Income-Squared & 1.1345 & 1.0603 & 1.07 & * \\
\hline
\end{tabular}


Fertility Intentions in Canada: Change or No Change?

Appendix A-2 (Continued)

\begin{tabular}{|c|c|c|c|c|}
\hline Explanatory Variable & Coefficient & $\begin{array}{c}\text { Standard } \\
\text { Error }\end{array}$ & t-value & $\begin{array}{c}\text { Predicted Mean } \\
\text { Intended Fertility } \\
\text { (Holding All Other } \\
\text { Variables at } \\
\text { Observed Mean) }\end{array}$ \\
\hline \multicolumn{5}{|l|}{ Social Factors } \\
\hline \multicolumn{5}{|l|}{ Nativity } \\
\hline Canada-Born (Reference Category) & & & & 2.12 \\
\hline Foreign-Born & -0.0125 & 0.0790 & -0.30 & 2.11 \\
\hline \multicolumn{5}{|l|}{ Religious Affiliation } \\
\hline No Religion & -0.1588 & 0.0810 & -1.09 & 1.96 \\
\hline Roman Catholic (Reference Category) & & & & 2.12 \\
\hline United Church & -0.1027 & 0.0760 & -1.02 & 2.02 \\
\hline Other Protestant & 0.0187 & 0.0610 & 0.52 & 2.14 \\
\hline Other Religion & -0.1310 & 0.0021 & 0.12 & -0.18 \\
\hline \multicolumn{5}{|l|}{ Religious Attendance } \\
\hline Weekly or More (Reference Category) & & & & 2.12 \\
\hline Monthly or More & -0.0233 & 0.0740 & -0.69 & 2.10 \\
\hline Few Times a Year & -0.0763 & 0.0670 & -1.31 & 2.05 \\
\hline At Least Once a Year & -0.1499 & 0.0960 & -2.09 & 1.97 \\
\hline Not at All & -0.0857 & 0.0660 & -1.78 & 2.04 \\
\hline \multicolumn{5}{|l|}{ Home Language } \\
\hline English Only (Reference Category) & & & & 2.12 \\
\hline French Only & -0.1390 & 0.0980 & -1.78 & 1.98 \\
\hline Other Home Language & 0.0264 & 0.0980 & 0.34 & 2.15 \\
\hline \multicolumn{5}{|l|}{ Household Factors } \\
\hline \multicolumn{5}{|l|}{ Multiple Generation Household } \\
\hline Category) & & & & 2.12 \\
\hline Multiple Generation & -0.5358 & 0.1580 & -3.88 & 1.59 \\
\hline Number of Persons in Household & 0.5914 & 0.0230 & 25.14 & $*$ \\
\hline \multicolumn{5}{|l|}{ Spatial Factors } \\
\hline \multicolumn{5}{|l|}{ Province } \\
\hline Newfoundland and Labrador & -0.4376 & 0.1050 & -4.32 & 1.68 \\
\hline Prince Edward Island & 0.0856 & 0.1460 & 0.41 & 2.21 \\
\hline Nova Scotia & -0.1578 & 0.0960 & -1.67 & 1.96 \\
\hline New Brunswick & -0.1534 & 0.1070 & -1.47 & 1.97 \\
\hline Quebec & -0.1037 & 0.0970 & -0.51 & 2.02 \\
\hline Ontario (Reference Category) & & & & 2.12 \\
\hline Manitoba & -0.1356 & 0.1000 & -1.36 & 1.99 \\
\hline Saskatchewan & -0.0483 & 0.0980 & -0.63 & 2.07 \\
\hline Alberta & 0.1119 & 0.0780 & 0.84 & 2.23 \\
\hline British Columbia & -0.1262 & 0.0840 & -2.36 & 2.00 \\
\hline \multicolumn{5}{|l|}{ Model Summary } \\
\hline R-Squared & 0.3928 & & & \\
\hline Standard Error of the Estimates & 0.8076 & & & \\
\hline Weighted Number of Observations & $3,942,949$ & & & \\
\hline Unweighted Number of Observations & 1,681 & & & \\
\hline
\end{tabular}

"See text for interpretation of the predicted mean fertility for continuous variables. 
Barry Edmonston, Sharon M. Lee and Zheng Wu

Appendix A-3

Regression Analysis for Mean Intended Fertility, Women in Married or Common-Law Unions, Aged 15 to 44 Years for Canada: 2001

\begin{tabular}{|c|c|c|c|c|}
\hline Explanatory Variable & Coefficient & $\begin{array}{l}\text { Standard } \\
\text { Error }\end{array}$ & t-value & $\begin{array}{c}\text { Predicted Mean } \\
\text { Intended Fertility } \\
\text { (Holding All Other } \\
\text { Variables at } \\
\text { Observed Mean) } \\
\end{array}$ \\
\hline Constant & 5.3447 & 0.4830 & 11.60 & \\
\hline \multicolumn{5}{|l|}{ Demographic Factors } \\
\hline \multicolumn{5}{|l|}{ Age of Respondent } \\
\hline Age & -0.2154 & 0.0280 & -7.96 & $*$ \\
\hline Age-Squared & 0.0022 & 0.0002 & 5.51 & $*$ \\
\hline \multicolumn{5}{|l|}{ Marital Status } \\
\hline Married (Reference Category) & & & & 2.20 \\
\hline Common-Law & 0.0145 & 0.1080 & 0.12 & 2.21 \\
\hline \multicolumn{5}{|l|}{ Number of Marriages } \\
\hline 0 Marriages & -0.1948 & 0.0940 & -2.27 & 2.00 \\
\hline 1 Marriage (Reference Category) & & & & 2.20 \\
\hline 2 Marriages & 0.1774 & 0.0740 & 2.04 & 2.38 \\
\hline 3+ Marriages & 0.9552 & 0.3600 & 2.87 & 3.15 \\
\hline \multicolumn{5}{|l|}{ Number of Common-Law Unions } \\
\hline 0 Unions Reference Category) & & & & 2.20 \\
\hline 1 Union & 0.0741 & 0.0740 & 1.04 & 2.27 \\
\hline 2 Unions & 0.0162 & 0.1060 & 0.62 & 2.22 \\
\hline $3+$ Unions & 0.4600 & 0.1760 & 2.90 & 2.66 \\
\hline \multicolumn{5}{|l|}{ Socioeconomic Status Factors } \\
\hline \multicolumn{5}{|l|}{ Employment } \\
\hline Working & -0.1475 & 0.0400 & -3.79 & 2.05 \\
\hline Unemployed & -0.4990 & 0.1660 & -1.89 & 1.70 \\
\hline $\begin{array}{l}\text { Not in the Labour Force (Reference Category } \\
\text { In School }\end{array}$ & & & & 2.20 \\
\hline Not in School (Reference Category) & & & & 2.20 \\
\hline In School & -0.3337 & 0.0930 & -2.34 & 1.87 \\
\hline \multicolumn{5}{|l|}{ Education } \\
\hline Elementary or Less (Reference Category) & & & & 2.20 \\
\hline Some Secondary & 0.0669 & 0.1640 & 0.37 & 2.27 \\
\hline Secondary Graduate & 0.0041 & 0.1590 & 0.12 & 2.20 \\
\hline Some Trade or Technical & 0.1292 & 0.2070 & 0.22 & 2.33 \\
\hline Some College & 0.1350 & 0.1720 & 0.93 & 2.33 \\
\hline Some University & 0.0783 & 0.1690 & 0.26 & 2.28 \\
\hline Trade or Technical Diploma & 0.0180 & 0.1670 & 0.01 & 2.22 \\
\hline College Diploma & 0.0876 & 0.1580 & 0.65 & 2.29 \\
\hline Bachelor's Degree and More & 0.2982 & 0.1590 & 1.84 & 2.50 \\
\hline \multicolumn{5}{|l|}{$100,000 \mathrm{~s})$} \\
\hline Household Income & -0.0563 & 0.0500 & -1.13 & $*$ \\
\hline Household Income-Squared & -0.4702 & 1.8808 & -0.25 & * \\
\hline
\end{tabular}


Fertility Intentions in Canada: Change or No Change?

Appendix A-3 (Continued)

\begin{tabular}{|c|c|c|c|c|}
\hline Explanatory Variable & Coefficient & $\begin{array}{c}\text { Standard } \\
\text { Error }\end{array}$ & t-value & $\begin{array}{c}\text { Predicted Mean } \\
\text { Intended Fertility } \\
\text { (Holding All Other } \\
\text { Variables at } \\
\text { Observed Mean) }\end{array}$ \\
\hline \multicolumn{5}{|l|}{ Social Factors } \\
\hline \multicolumn{5}{|l|}{ Nativity } \\
\hline Canada-Born (Reference Category) & & & & 2.20 \\
\hline Foreign-Born & 0.0904 & 0.0620 & 1.35 & 2.29 \\
\hline \multicolumn{5}{|l|}{ Religious Affiliation } \\
\hline No Religion & -0.1458 & 0.0620 & -2.29 & 2.05 \\
\hline Roman Catholic (Reference Category) & & & & 2.20 \\
\hline United Church & -0.0767 & 0.0650 & -1.22 & 2.12 \\
\hline Other Protestant & -0.0058 & 0.0470 & -1.31 & 2.19 \\
\hline Other Religion & 0.0747 & 0.0850 & 0.67 & 2.27 \\
\hline \multicolumn{5}{|l|}{ Religious Attendance } \\
\hline Weekly or More (Reference Category) & & & & 2.20 \\
\hline Monthly or More & -0.1392 & 0.0630 & -2.38 & 2.06 \\
\hline Few Times a Year & -0.0043 & 0.0550 & -1.66 & 2.20 \\
\hline At Least Once a Year & -0.2531 & 0.0730 & -3.21 & 1.95 \\
\hline Not at All & -0.2003 & 0.0560 & -3.62 & 2.00 \\
\hline \multicolumn{5}{|l|}{ Home Language } \\
\hline English Only (Reference Category) & & & & 2.20 \\
\hline French Only & -0.3093 & 0.0870 & -3.53 & 1.89 \\
\hline Other Home Language & -0.1581 & 0.0790 & -1.21 & 2.04 \\
\hline \multicolumn{5}{|l|}{ Household Factors } \\
\hline \multicolumn{5}{|l|}{ Multiple Generation Household } \\
\hline Category) & & & & 2.20 \\
\hline Multiple Generation & -0.5045 & 0.1520 & -2.89 & 1.69 \\
\hline Number of Persons in Household & 0.5277 & 0.0190 & 27.75 & * \\
\hline \multicolumn{5}{|l|}{ Spatial Factors } \\
\hline \multicolumn{5}{|l|}{ Province } \\
\hline Newfoundland and Labrador & -0.1462 & 0.0800 & -1.51 & 2.05 \\
\hline Prince Edward Island & 0.0307 & 0.1050 & 0.09 & 2.23 \\
\hline Nova Scotia & -0.0641 & 0.0790 & -0.87 & 2.14 \\
\hline New Brunswick & -0.0129 & 0.0740 & -0.98 & 2.19 \\
\hline Quebec & 0.2436 & 0.0860 & 2.56 & 2.44 \\
\hline Ontario (Reference Category) & & & & 2.20 \\
\hline Manitoba & 0.1470 & 0.0840 & 1.91 & 2.35 \\
\hline Saskatchewan & 0.2121 & 0.0830 & 2.02 & 2.41 \\
\hline Alberta & -0.0094 & 0.0630 & -0.32 & 2.19 \\
\hline British Columbia & 0.1335 & 0.0620 & 1.89 & 2.33 \\
\hline \multicolumn{5}{|l|}{ Model Summary } \\
\hline R-Squared & 0.3164 & & & \\
\hline Standard Error of the Estimates & 0.9265 & & & \\
\hline Weighted Number of Observations & $4,100,015$ & & & \\
\hline Unweighted Number of Observations & 3,165 & & & \\
\hline
\end{tabular}

"See text for interpretation of the predicted mean fertility for continuous variables. 
Barry Edmonston, Sharon M. Lee and Zheng Wu

Appendix A-4

Regression Analysis for Mean Intended Fertility, Women in Married or Common-Law Unions, Aged 15 to 44 Years for Canada: 2006

\begin{tabular}{|c|c|c|c|c|}
\hline Explanatory Variable & Coefficient & $\begin{array}{c}\text { Standard } \\
\text { Error }\end{array}$ & t-value & $\begin{array}{c}\text { Predicted Mean } \\
\text { Intended Fertility } \\
\text { (Holding All Other } \\
\text { Variables at } \\
\text { Observed Mean) }\end{array}$ \\
\hline Constant & 4.7322 & 0.4810 & 10.57 & \\
\hline \multicolumn{5}{|l|}{ Demographic Factors } \\
\hline \multicolumn{5}{|l|}{ Age of Respondent } \\
\hline Age & -0.2156 & 0.0280 & -8.23 & * \\
\hline Age-Squared & 0.0024 & 0.0001 & 6.30 & * \\
\hline \multicolumn{5}{|l|}{ Marital Status } \\
\hline Married (Reference Category) & & & & 2.12 \\
\hline Common-Law & 0.0640 & 0.1010 & 0.50 & 2.18 \\
\hline \multicolumn{5}{|l|}{ Number of Marriages } \\
\hline 0 Marriages & -0.1411 & 0.0910 & -1.79 & 1.97 \\
\hline 1 Marriage (Reference Category) & & & & 2.12 \\
\hline 2 Marriages & 0.1680 & 0.0750 & 2.67 & 2.28 \\
\hline 3+ Marriages & 0.4184 & 0.2710 & 1.44 & 2.53 \\
\hline \multicolumn{5}{|l|}{ Number of Common-Law Unions } \\
\hline 0 Unions Reference Category) & & & & 2.12 \\
\hline 1 Union & -0.0600 & 0.0620 & -0.64 & 2.06 \\
\hline 2 Unions & -0.0872 & 0.0910 & -0.07 & 2.03 \\
\hline $3+$ Unions & 0.0053 & 0.1560 & 0.38 & 2.12 \\
\hline \multicolumn{5}{|l|}{ Socioeconomic Status Factors } \\
\hline \multicolumn{5}{|l|}{ Employment } \\
\hline Working & -0.1113 & 0.0370 & -2.14 & 2.00 \\
\hline Unemployed & -0.1451 & 0.1410 & -0.24 & 1.97 \\
\hline Not in the Labour Force (Reference Category & & & & 2.12 \\
\hline \multicolumn{5}{|l|}{ In School } \\
\hline Not in School (Reference Category) & & & & 2.12 \\
\hline In School & 0.0913 & 0.0880 & 1.65 & 2.21 \\
\hline \multicolumn{5}{|l|}{ Education } \\
\hline Elementary or Less (Reference Category) & & & & 2.12 \\
\hline Some Secondary & 0.2693 & 0.1610 & 0.83 & 2.39 \\
\hline Secondary Graduate & 0.1206 & 0.1520 & 0.42 & 2.24 \\
\hline Some Trade or Technical & 0.1072 & 0.1790 & 0.39 & 2.22 \\
\hline Some College & 0.0153 & 0.1600 & 0.02 & 2.13 \\
\hline Some University & 0.2572 & 0.1630 & 0.97 & 2.37 \\
\hline Trade or Technical Diploma & 0.0318 & 0.1520 & 0.21 & 2.15 \\
\hline College Diploma & 0.1895 & 0.1490 & 0.67 & 2.31 \\
\hline Bachelor's Degree and More & 0.2403 & 0.1490 & 1.36 & 2.36 \\
\hline \multicolumn{5}{|l|}{$100,000 \mathrm{~s})$} \\
\hline $\begin{array}{l}\text { Household Income } \\
\text { Household Income-Squared }\end{array}$ & $\begin{array}{l}-0.0638 \\
-0.5927\end{array}$ & $\begin{array}{l}0.1181 \\
3.1190\end{array}$ & $\begin{array}{l}-0.54 \\
-0.19\end{array}$ & $*$ \\
\hline
\end{tabular}


Fertility Intentions in Canada: Change or No Change?

Appendix A-4 (Continued)

\begin{tabular}{|c|c|c|c|c|}
\hline Explanatory Variable & Coefficient & $\begin{array}{c}\text { Standard } \\
\text { Error }\end{array}$ & t-value & $\begin{array}{c}\text { Predicted Mean } \\
\text { Intended Fertility } \\
\text { (Holding All Other } \\
\text { Variables at } \\
\text { Observed Mean) }\end{array}$ \\
\hline \multicolumn{5}{|l|}{ Social Factors } \\
\hline \multicolumn{5}{|l|}{ Nativity } \\
\hline Canada-Born (Reference Category) & & & & 2.12 \\
\hline Foreign-Born & -0.0737 & 0.0520 & -0.91 & 2.04 \\
\hline \multicolumn{5}{|l|}{ Religious Affiliation } \\
\hline No Religion & -0.1184 & 0.0490 & -2.86 & 2.00 \\
\hline Roman Catholic (Reference Category) & & & & 2.12 \\
\hline United Church & -0.1263 & 0.0640 & -2.52 & 1.99 \\
\hline Other Protestant & 0.0841 & 0.0440 & 0.92 & 2.20 \\
\hline Other Religion & 0.0244 & 0.0690 & 0.45 & 2.14 \\
\hline \multicolumn{5}{|l|}{ Religious Attendance } \\
\hline Weekly or More (Reference Category) & & & & 2.12 \\
\hline Monthly or More & -0.0993 & 0.0600 & -2.10 & 2.02 \\
\hline Few Times a Year & -0.1052 & 0.0520 & -2.11 & 2.01 \\
\hline At Least Once a Year & -0.0576 & 0.0640 & -1.11 & 2.06 \\
\hline Not at All & -0.1748 & 0.0510 & -3.75 & 1.94 \\
\hline \multicolumn{5}{|l|}{ Home Language } \\
\hline English Only (Reference Category) & & & & 2.12 \\
\hline French Only & -0.0404 & 0.0750 & -0.11 & 2.08 \\
\hline Other Home Language & -0.0135 & 0.0670 & -0.61 & 2.10 \\
\hline \multicolumn{5}{|l|}{ Household Factors } \\
\hline \multicolumn{5}{|l|}{ Multiple Generation Household } \\
\hline Category) & & & & 2.12 \\
\hline Multiple Generation & -0.4980 & 0.1130 & -4.62 & 1.62 \\
\hline Number of Persons in Household & 0.5760 & 0.0170 & 34.17 & * \\
\hline \multicolumn{5}{|l|}{ Spatial Factors } \\
\hline \multicolumn{5}{|l|}{ Province } \\
\hline Newfoundland and Labrador & -0.1264 & 0.0740 & -1.36 & 1.99 \\
\hline Prince Edward Island & 0.0115 & 0.0920 & 0.16 & 2.13 \\
\hline Nova Scotia & -0.0909 & 0.0740 & -0.97 & 2.02 \\
\hline New Brunswick & -0.0395 & 0.0730 & -1.25 & 2.08 \\
\hline Quebec & 0.1541 & 0.0730 & 1.06 & 2.27 \\
\hline Ontario (Reference Category) & & & & 2.12 \\
\hline Manitoba & 0.0968 & 0.0780 & 1.52 & 2.21 \\
\hline Saskatchewan & 0.2147 & 0.0570 & 2.62 & 2.33 \\
\hline Alberta & 0.1475 & 0.0550 & 2.67 & 2.26 \\
\hline British Columbia & 0.0602 & 0.0910 & 1.20 & 2.18 \\
\hline \multicolumn{5}{|l|}{ Model Summary } \\
\hline R-Squared & 0.3856 & & & \\
\hline Standard Error of the Estimates & 0.8019 & & & \\
\hline Weighted Number of Observations & $3,415,315$ & & & \\
\hline Unweighted Number of Observations & 2,769 & & & \\
\hline
\end{tabular}

"See text for interpretation of the predicted mean fertility for continuous variables. 